\title{
Matrix metalloproteinases and their tissue inhibitors at the ovine trophoblast-uterine interface
}

\author{
L. A. Salamonsen ${ }^{1}$, H. Nagase ${ }^{2}$ and D. E. Woolley ${ }^{3}$ \\ ${ }^{1}$ Prince Henry's Institute of Medical Research, PO Box 152, Clayton, Victoria 3168, Australia; \\ ${ }^{2}$ Department of Biochemistry and Molecular Biology. University of Kansas Medical Center, \\ Kansas City, Kansas 66103, USA; and ${ }^{3}$ University Hospital of South Manchester. West Didsbury, \\ Manchester M20 8LR, UK
}

\begin{abstract}
Trophoblast invasiveness in ruminants is limited to fusion of migrating binucleate cells with uterine epithelium, but considerable tissue remodelling and angiogenesis occurs within the endometrium at implantation. Such processes are elsewhere associated with an altered balance of matrix metalloproteinases (MMPs) and their tissue inhibitors (TIMPs). ProMMPs- $-,-2,-3$ are secreted by cultured ovine endometrial stromal, but not epithelial, cells and expression of proMMP-1 and proMMP- 3 is inhibited by interferon $\tau$, the dominant preimplantation trophoblast product, independently of its effects on prostaglandin production. Messenger RNA for TIMP-I and TIMP-2 is expressed in endometrium throughout the oestrous cycle and early pregnancy. Both TIMP-I mRNA ( $0.9 \mathrm{~kb}$ transcript) and TIMP-2 mRNA (1.0 kb transcript) expression increase at day 12 through to day 20 , suggesting a role in preventing trophoblast invasion. Expression of the $3.5 \mathrm{~kb}$ transcript for TIMP-2 decreases from day 16 and is undetectable on day 20 . Uterine flushings from both nonpregnant and pregnant ewes on day 16 after oestrus contain proMMP-2, possibly transudated from plasma, and proMMP-9, but concentrations are higher in pregnancy. These enzymes are also detected in conditioned medium following culture of trophoblasts at days 16-20. Whether the trophoblast MMPs have a role in implantation in sheep remains to be established. The production of MMPs and TIMPs in the endometrium and the changes associated with implantation events suggest that they contribute to the marked endometrial remodelling associated with early placentation.
\end{abstract}

\section{Introduction}

The processes of implantation and placentation are accompanied by considerable tissue remodelling and angiogenesis, although it is not known how these are regulated at the molecular and cellular level. In ruminants, the trophoblast does not invade through the uterine epithelium and into the uterine stroma, as it does in many other species, although pig trophoblast, which is similarly non-invasive in vivo, does have invasive capacity as demonstrated by its ability to penetrate epithelium and develop in ectopic sites (Samuel, 1971). Establishment of the synepitheliochorial placenta (as in cattle and sheep; Wooding and Flint, 1994) involves both remodelling of the tissue and development of new blood vessels. At implantation, there is fusion of fetal chorionic binucleate cells with those of the uterine epithelium and formation of mini-syncytia in contact with the maternal connective tissue (Wooding 1982, 1984; Lee et al., 1985). Considerable reorganization of the vessels is required to bring them into close proximity with the trophoblast tissue, so that the conceptus can be provided with the required wide range of metabolites and hormones and high rates of $\mathrm{O}_{2}$ and $\mathrm{CO}_{2}$ exchange. In sheep, marked changes in the 


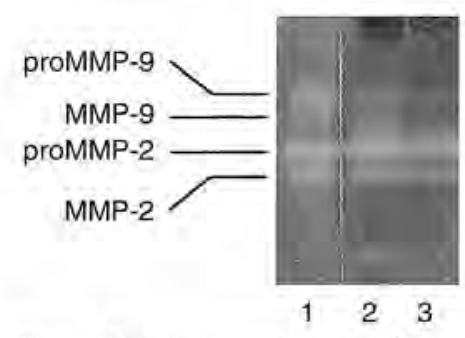

Fig. 4. Gelatin zymogram of enzymes from conditioned medium following culture of trophoblast tissue from two ewes at day 17 of pregnancy (lanes 2 and 3). Standard (lane 1) is culture medium from cultured human endometrial cells as described by Rawdanowicz et al. (1994).

include MMP-I and MMP-3) were detected, the production of MMP-3 by ovine trophoblast seems unlikely.

\section{Tissue Inhibitors of Metalloproteinases in the Endometrium}

Tissue inhibitors of metalloproteinases (TIMPs) have been implicated in the regulation of angiogenesis (Moses et al., 1990), cell growth (Westbrook et al., 1984; Hayakawa et al., 1992) and differentiation (Docherty ef al., 1985), and expression of their mRNA has been demonstrated in the mouse uterus during gestation (Waterhouse et al, 1993). However, nothing is known of their expression in the endometrium of ruminants.

We have examined normal endometrial tissue for expression of TIMPs- 1 and -2 during early pregnancy. Endometrial tissue was collected on specified days after mating (days $4-20 ; n=2-6$ ewes per day) after hysterectomy of anaesthetized ewes. Total RNA was isolated from tissue samples and subjected to northern blot analysis. Complementary CDNA probes against ovine TIMP-I and TIMP-2 were generously provided by M. Smith (Missouri) and an oligonucleotide probe against ribosomal RNA (18S) by P. Fuller (Melbourne). Relative intensities of the transcript encoding TIMP-1 $(0.9 \mathrm{~kb})$ and the two transcripts encoding TIMP-2 (3.5 kb and $1.0 \mathrm{~kb})$ were calculated after correction for loading (Fig. 5). The relative abundance of mRNA for TIMP-I increased from very early pregnancy (up until day 10) to the time of trophoblast expansion (days 12-14) and remained high until day 20. The relative abundance of the $1.0 \mathrm{~kb}$ transcript for TIMP-2 followed a similar pattern, but for the $3.5 \mathrm{~kb}$ transcript, the abundance decreased from day 16 and was undetectable on day 20. The origin of the two transcripts for TIMP-2 is not known, although it was suggested that alternative splicing of $5^{\prime}$ untranslated regions may occur (Stetler-Stevenson et al., 1990). The significance of the relative differences in the changes of abundance of the two transcripts during early pregnancy is not known, but the results suggest that the conceptus inhibits the expression of the $3.5 \mathrm{~kb}$ transcript immediately after implantation. As there is very rapid development of the vasculature into the areas immediately underlying the luminal epithelium coincident with this decreased expression of the $3.5 \mathrm{~kb}$ transcript (Reynolds and Redmer, 1992), it will be important to establish whether there is a functional relationship between the two transcripts. By contrast, the increased expression of mRNA encoding TIMP-I and for the $1.0 \mathrm{~kb}$ transcript of TIMP-2 coincident with implantation may play an important role in preventing degradation of the maternal-trophoblast interface by the trophoblast MMPs.

\section{Conclusions}

It is clear that in sheep, as in other species, the trophoblast produces proMMP-2 and proMMP-9. Because of the non-invasive nature of implantation in ewes, it is not clear at this stage whether these 

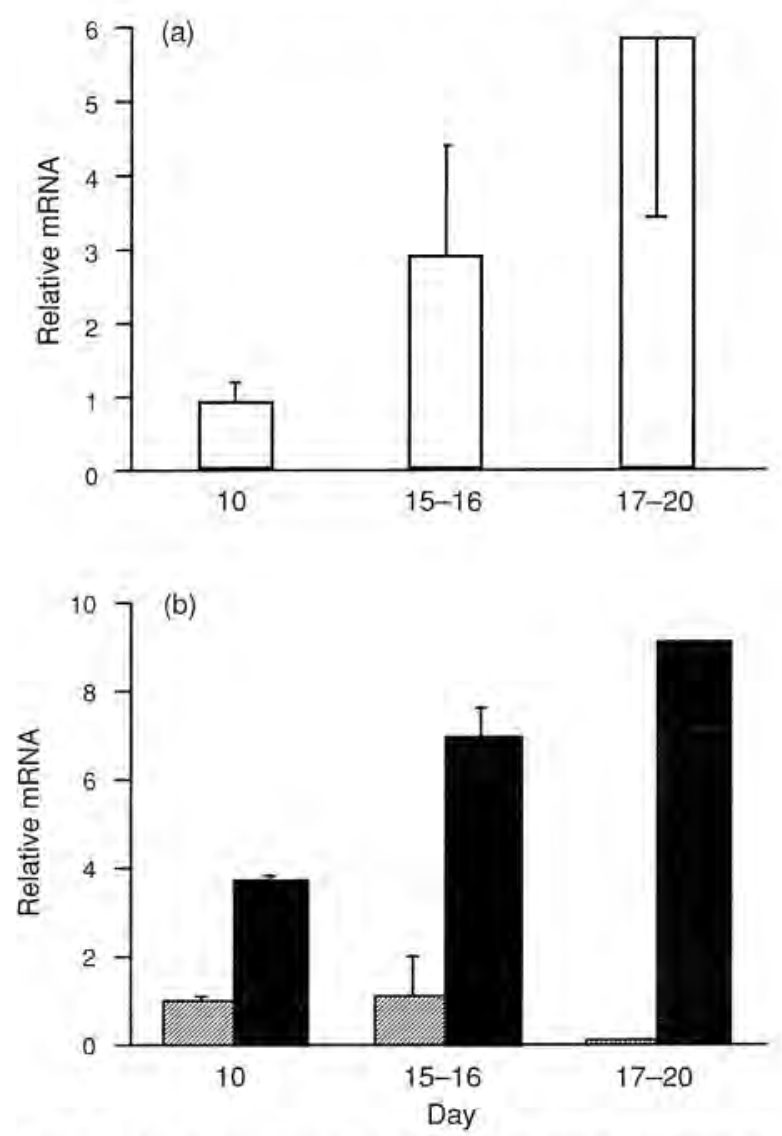

Fig. 5. Relative abundance of mRNA for tissue inhibitor of metalloproteinase 1 (TIMP-1) and TIMP- 2 in the ovine endometrium during the oestrous cycle and early pregnancy. (a) TIMP-1, $0.9 \mathrm{~kb}$, (b) TIMP-2, $1.0 \mathrm{~kb}$ and ETIMP-2, $3.5 \mathrm{~kb}$. Data derived from densitometry of northern blots probed with cDNA probes for ovine TIMP-1 and TIMP-2. An oligonucleotide probe for rat $18 \mathrm{~S}$ ribosomal RNA was used to assess the amount and integrity of total RNA loaded in each case.

enzymes, the primary substrates of which are thought to be basement membrane components, have a function in establishing the close relationship between maternal uterine epithelium and trophoblast leading to the establishment of the synepitheliochorial placenta, or whether they are produced as a result of evolution but are redundant in this species. Activators of the enzymes have not yet been identified at implantation sites in ewes. For proMMP-2, the only known natural activator is the membrane-type MMP, whereas activators of proMMP-9 include trypsin, cathepsin G, chymotrypsin and MMP-3. The presence of TIMPs, or other, less specific protease inhibitors, such as $\alpha_{2}$-macroglobulin, in the uterine environment may play an important role in preventing actions of MMPs at the endometrial-trophoblast interface.

It is much more likely that MMPs play a role in the profound tissue remodelling within the stroma of the caruncles immediately after implantation. The decreased thickness of the uterine endometrium, substantial increase in the number of blood vessels and the development of a subepithelial microvascular plexus are all processes to which extracellular matrix degradation is fundamental. Furthermore, the reorganization of the uterine epithelium from the columnar morphology seen on day 16 to the thin, 
flattened morphology observed on day 22 is presumably related to the nature and distribution of the microfilaments within the cell, which in turn are determined by their attachment to the components of the extracellular matrix. There have been no studies describing changes in the extracellular matrix relating to these events. Definition of such changes, how they may be brought about by MMPs, and how production and activation of MMPs and production of TIMPs are regulated within the uterus and the trophoblast remain to be established.

This work was supported by the NH and MRC of Australia (to L. A. Salamonsen) and by National Institutes of Health Grants AR39189 (to H. Nagase). The authors thank R. Suzuki. A. Butt and A. Hampton for excellent technical assistance and S. Pankridge for presentation of the figures.

\section{References}

Badinga L, Michel FJ, Fields MJ, Sharp DC and Simmen RCM (1994) Pregnancy-associated endometrial expression of antileukoproteinase gene is correlated with epitheliochorial placentation Molectiar Reproduction and Developmeni 38 357-363

Birkedal-Hansen $\mathrm{H}$, Moore WGL, Bodden MK, Windsor LJ, Birkedal-Hansen B, De Carlo A and Engler JA (1993) Matrix metalloproteinasès: a review Critical Retieios of Oral Biology and Medicine 4 199-250

Bischof P, Friedli E, Martelli M and Campana A (1991) Expression of extracellular matrix-degrading metalloproteinases by cultured human cytotrophoblast cells: effects of cell adhesion and immunopurification American Joumal of Obstetrics and Gynecology 165 1791-1801

Brenner CA, Adder RA, Rappolee DA, Pedersen RA and Werb Z (I989) Genes for extracellular matrix degrading metalloproteinases and their inhibitor, TIMP, are expressed during early mammalian development Genes and Development 3 $848-859$

Cherny RA and Findlay JK (1990) Separation and cultures of ovine endometrial and stromal cells: evidence of morphological and functional polarity Biology of Reproduction 43 $241-250$

Docherty AJP, Lyons A, Snith B], Wright EM, Stephens PE, Harris TJR, Murphy G and Reynolds J (1985) Sequence of human tissue inhibitor of metalloproteinases and its identity to erythroid-potentiating activity Nature 318 66-69

Fazleabas AT, Geisert RD, Bazer FW and Roberts RM (1983) Relationship between release of plasminogen activator and estrogen by blastocysts and secretion of plasmin inhibitor by uterine endometrium in the pregnant pig Biology of Reproduction $29225-238$

Fernandez PL, Merino MJ, Nogales FF, Charonois AS, Stetler-Stevenson W and Liotta L (1992) Immunohistochemical profile of basement membrane proteins and 72 kilodalton type IV collagenase in the implantation placental site Laboratory Investigation $66572-579$

Fisher SJ, Cui T-Y, Zhang L, Hartman L, Grahl K, Guo-yang Z, Tarpey J and Damsky CH (1989) Adhesive and degradative properties of human placental cytotrophoblast cells in vitro Joumal of Cell Biology $109891-902$

Francis H, Keisler DH and Roberts RM (1991) Induction of the synthesis of the pregnancy-specific protein, $p 70$ by intramuscular injection of recombinant bovine interferon- $\alpha 11$ into non-pregnant ewes Journal of Reproduction and Fertility $93 \quad 367-374$
Godkin JD, Bazer FW and Roberts RM (1984) Ovine trophoblast protein $I$, an early secreted blastocyst protein, binds specifically to uterine endometrium and affects protein synthesis Endocinology 114 120-130

Hampton AL and Salamonsen L.A (1994) Endometrial expression of messenger ribonucleic acid encoding matrix metalloproteinases and their tissue inhibitors coincides with menstruation Joumal of Endocrinology $141 \mathrm{R} 1-\mathrm{R} 3$

Hayakawa T, Yamashita K, Tanzawa K, Uchijima E and lwata K (1992) Tissue inhubitor of metalloproteinases from human bone marrow stromal cell line KM 102 has erythroidpotentiating activity, suggesting its possibly bifunctional role in the hematopoietic environment FEBS Letters 298 29-32

Lee CS, Gogolin-Ewans K, White TR and Brandon MR (1985) Studies on the distribution of binucleate cells in the placenta of sheep with a monoclonal antibody SBU-3 Joumal of Anatomy $140565-576$

Leslie MV and Hansen PJ (1991) Progesterone-regulated secretion of the serpin-like proteins of the ovine and bovine uterus Steroids $56 \quad 589-597$

Librach CL, Werb Z, Fitzgerald ML, Chiu K, Corwin NM, Esteves RA, Grobelny D, Galardy R, Damsky $\mathrm{CH}$ and Fisher S] (1991) $92-\mathrm{kD}$ type IV collagenase mediates invasion of human cytotrophoblasts Joumal of Cell Biology 113 $437-449$

Liotta LA, Steeg PS and Stetler-Stevenson WG (1991) Cancer metastasis and angiogenesis: an imbalance of positive and negative regulation Coll $64 \quad 327-336$

Morodomi T, Ogata Y, Sasaguri Y, Morimatsu M and Nagase H (1992) Purification and characterization of matrix metalloproteinase 9 from U937 monocytic leukemia and HT1080 fibrosarcoma cells Biochemical Journal 285 603-611

Moscatelli D and Rifkin DB (1988) Membrane and matrix localization of proteinases: a common theme in tumor cell invasion and angiogenesis Biochimica et Bioplysica Acta 948 67-85

Moses MA, Sudhalter J and Langer R (1990) Identification of an inhibitor of neovascularization from cartilage Science $\mathbf{2 4 8}$ 1408-1410

Mullins DE, Horst MN, Bazer FW and Roberts RM (1980) Secretion of a progesterone-induced inhibitor of plasminagen activator by the porcine uterus Coll 20 865-872

Nagase H (1991) Matrix metalloproteinases I, 2 and 3: substrate specificities and activation mechanisms. In The Extracellular Malrix of the Uterus, Ceroix and Fetal 
Membranes: Synthesis, Degradation and Hormonal Regulation. Eds PCleppert and IF Woessner. Perinatology Press, Ithaca, New York

Nagase H, Barrett AJ and Woessner JF (1992) Nomenclature and glossary of the matrix metalloproteinases Matrix Supplement 1 421-424

Ogata Y, Enghild J and Nagase H (1992) Matrix metalloproteinase 3 (stromelysin) activates the precursor for the human matrix metalloproteinase 9 journal of Biological Chemistry $2673581-3584$

Okada Y, Gononji Y, Naka K, Tomita K, Nakanishi I, Iwata K, Yamashita K and Hayakawa T (1992) Matrix metalloproteinase 9 (92-kDa gelatinase/type IV collagenase) from HT1080 human fibrosarcoma cells. Purification and activation of the precursor and enzymic properties Joumal of Biological Chemistry $26721712-21719$

Rawdanowicz TJ, Hampton AL, Nagase H, Woolley DE and Salamonsen LA (1994) Matrix metalloproteinase secretion by cultured human endometrial stromal cells: identification of interstitial collagenase, gelatinase A. gelatinase B and stromelysin. I. Differential regulation by interleukin- $\mathrm{I} \alpha$ and tumor necrosis factor $\beta$ Joumal of Clinical Endocrinology and Mefabolism 49 530-530

Reynolds LP and Redmer DA (I992) Growth and microvascular development of the uterus during early pregnancy in ewes Biology of Reproduction 47 o98-708

Roberts RM, Cross JC and Leaman DW (1992) Interferons as hormones of pregnancy Endocrine Reviews 13 432-452

Roberts RM, Mathialagan N. Stallings-Mann ML, Duffy JY and Trout WE Proteinase inhibitors at the trophoblast-uterine interface: role in implantation or immunomodulation? In Molecular and Cellular Aspects of Periimplantation Processes (Serono Symposin LISA) Ed. SK Dey. Springer Verlag. New York (in press)

Salamonsen LA, Doughton B and Findlay JK (1984) Protein synthesis by preimplantation sheep blastocysts. In Reproduction in Sheep. pp 115-117 Eds DA Lindsay and DT Pearce. Australian Academy of Sciences, Canberra

Salamonsen LA, Stuchbery SJ, O'Grady CM, Godkin JD and Findlay JK (1988) Interferon mimics effects of ovine trophoblast protein 1 on prostaglandin and protein secretion by ovine endometrial cells in vitro Joumal of Endocrinology $117 \mathrm{R} 1-\mathrm{R} 4$

Salamonsen LA, Nagase H and Woolley DE (1991) Production of matrix metalloprotemase 3 (stromelysin) by cultured ovine endometrial cells Joumal of Cell Science 100 381-385

Salamonsen LA, Nagase H, Suzuki R and Woolley DE (1993) Production of matrix metalloproteinase I (interstitial collagenase) and matrix metalloproteinase 2 (gelatinase A $72 \mathrm{kDa}$ gelatinase) by ovine endometrial cells in vilro: different regulation and preferential expression by stromal fibroblasts Joumal of Reproduction and Fertility 98 583-589

Salamonsen LA, Hampton AL, Suzuki R and Nagase H (1994) Modulation of production of matrix metalloproteinases from ovine endometrial cells by ovine trophoblast interferon Joumal of Reproduction and Fertility 102 155-162

Salamonsen LA, Suzuki R, Nagase $\mathrm{H}$ and Woolley DE Matrix metalloproteinases, a role in implantation? In Endocrinology of Embryo-Endometrial Interactions Ed. SR Glasser. Plenum Presss, New York (in préss).
Samuel CA (1971) The development of pig trophoblast in ectopic sites Journal of Reproduction and Fertility 27 494-495

Sato H, Takino I, Okada Y, Cao J, Shinagawa A, Yamamoto E and Seiki M (1994) A matrix metalloproteinase expressed on the surface of invasive tumour cells Nature 370 61-65

Schlafke S, Welsh AO and Enders AC (1985) Penetration of the basal lamina of the uterine luminal epithelium during implantation in the rat Anatomical Record 212 47-56

Simmen RC, Michel FJ. Fliss AE, Smith LC and Fliss MF (1992) Ontogeny. immunocytochemical localization and biochemical properties of the pregnancy-associated uterin elastase/cathepsin-G protease inhibitor, antileukoproteinase (ALP): monospecific antibodies to a synthetic peptide recognize native ALP Endocrinology 130 1957-1965

Smith SE, Cullen WC and Godkin JD (1990) Ultrastructural morphometric analysis of the uterine epithelium during early pregnancy in the sheep Joumal of Reproduction and Fertility $89 \quad 517-525$

Stetler-Stevenson WG, Brown PD, Onisto $\mathrm{M}$, Levy AT and Liotta LA (1990) Tissue inhibitor of metalloproteinases-2 (TIMP-2) mRNA expression in tumor cell lines and human tumor tissues Jommal of Biological Clemistry 265 $13933-13938$

Vallet JL, Barker PJ, Lamming GE, Skinner N and Huskisson NA (1991) A low molecular weight endometrial secretory protein which is increased by ovine trophoblast protein-1 is a B2-microglobulin-like protein Joumal of Endocrinalogy 130 RI-R4

Waterhouse P, Denhardt DT and Khokha R (1993) Temporal expression of tissue inhibitors of metalloproteinases in mouse reproductive tissues during gestation Molecular Reproduction and Development 35 219-226

Welsh AO and Enders AC (1989) Comparison of the ability of cells from rat and mouse blastocysts and rat uterus to alter complex extracellular matrix in vitro In Blastocyst Implantation, p 55 Ed. K Yoshinaga. Adams Publishing Group, Boston

Westbrook CA, Gasson JC, Gerber SE, Selsted ME and Golde DW (1984) Purification and characterization of human T-lymphocyte-derived erythroid-potentiating activity Journal of Biological Chernistry $2599992-9996$

Woessner JF, Ir (1991) Matrix metalloproteinases and their inhibitors in connective tissue remodelling FASEB Joumal 5 2145-2154

Wooding FBP (1982) The role of the binucleate cell in ruminant placental structure Joumal of Reproduction and Fertility Supplement 31 31-39

Wooding FBP (1984) Role of binucleate cells in fetomaternal cell fusion at implantation in the sheep American joumal of Anatomy 170 233-250

Wooding FBP and Flint APF (1994) Placentation. In Marshall's Physiology of Reproduction Vol. 3, Pregnancy and Lactation. pp 235-460 Ed. GE Lamming. Chapman and Hall, London

Xie SC, Low BG, Nagel RJ, Kramer KK, Anthony RV, Zoli AP, Beckers JF and Roberts RM (1991) Identification of the major pregnancy-specific antigens of cattle and sheep as inactive members of the aspartic proteinase family Proccedings of the National Academy of Sciences USA 88 $10247-10251$ 


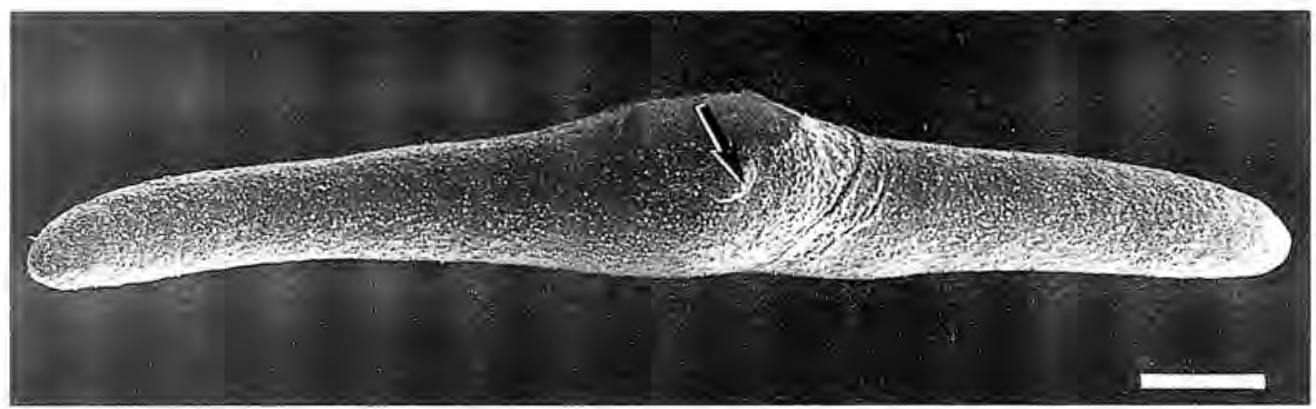

Fig. 1. Scanning electron micrograph of a day-14 bovine conceptus at the elongation stage. The arrow shows the protruding embryonic disc. Scale bar represents $500 \mu \mathrm{m}$.

\section{Pre-attachment Period}

The embryo enters into the uterus by day $4-5$ at the morula stage and the blastocyst is formed at about day 6 . Hatching from the zona pellucida occurs at day 8 and day 10 in sheep and cows respectively. Elongation of the blastocyst occurs by day 11 (sheep), 13 (cows and goats) and 3-4 days later it increases rapidly to give rise to a filamentous conceptus which is more than $10 \mathrm{~cm}$ long with a protruding embryonic disc located near the middle (Fig. I). At the end of the elongation process the conceptus occupies the full length of the uterine horn ipsilateral to the corpus luteum and, in single pregnancies, it migrates partly into the contralateral horn. At this stage the inner face of the extra-embryonic trophoblast is lined by the endoderm and by the growing yolk sac in the embryonic area. The trophoblast is composed of cuboidal cells that display the structural features of a polarized epithelium with numerous apical microvilli, lateral membranes united by tight junctions and desmosomes and a basal pole resting on a basal lamina. Moreover, many of the cytoskeletal proteins that characterize epithelial cells are present in the trophoblast cells (Guillomot and Fléchon, 1990).

During this period of free-life, nutrition of the conceptus is histotrophic and depends on uterine secretions. Most of the endometrial secretory activity occurs during the luteal phase of the oestrous cycle and is controlled by progesterone (Bazer et al., 1981). The luminal epithelial cells show typical cytoplasmic protrusions that characterize cells with an apocrine mode of secretion. Initially restricted to the intercaruncular epithelium, these secretory processes become evident on the caruncular epithelium as pregnancy progresses (Guillomot et al. 1981; Guillomot and Guay, 1982). Although many studies have documented the fact that the endometrium has a specific secretory activity during early pregnancy, few uterine proteins have been characterized in ruminants (Guillomot et al., 1988). Recently a retinol-binding protein (RBP) has been identified as a major component of the uterine secretions in cows (Liu and Godkin, 1992; Thomas et al., 1992) and in sheep (Dore et al., 1992). Endometrial expression of RBP increases during the luteal phase of the cycle and during the pre-attachment period of pregnancy but decreases thereafter in the uterus of pregnant animals (Harney et al., 1993). These observations suggest that RBP, the vitamin A transport protein, is essential during rapid growth of the conceptus. The trophoblastic cells exhibit ultrastructural features that indicate a high capacity for absorption of extracellular material. Cell debris and cilia from uterine ciliated cells are trapped in between the network of apical microvilli. The presence of numerous endocytotic vesicles, lysosomes, lipid droplets and proteinaceous crystal bodies support the contention that intense absorptive and storage activities occur in the trophoblast (Wintenberger-Torrès and Fléchon, 1974; Carnegie et al., 1985). The precise nature of the various products ingested by the trophoblastic cells is still unknown. Immunocytochemistry studies have shown that the crystal bodies are associated with a $14 \mathrm{kDa}$ protein (14 K protein) (Wooding et al, 1991). This protein is also present in the uterine epithelium, where it is found in both the cell cytoplasm and the nuclei (Kazemi et al., 1990). The $14 \mathrm{kDa}$ protein is progesterone dependent since it increases in the uterine fluid during the luteal phase of the oestrous cycle and is induced by progesterone in ovariectomized ewes (Kazemi et al., 1990). However, a uterine origin of the $14 \mathrm{kDa}$ protein was not 

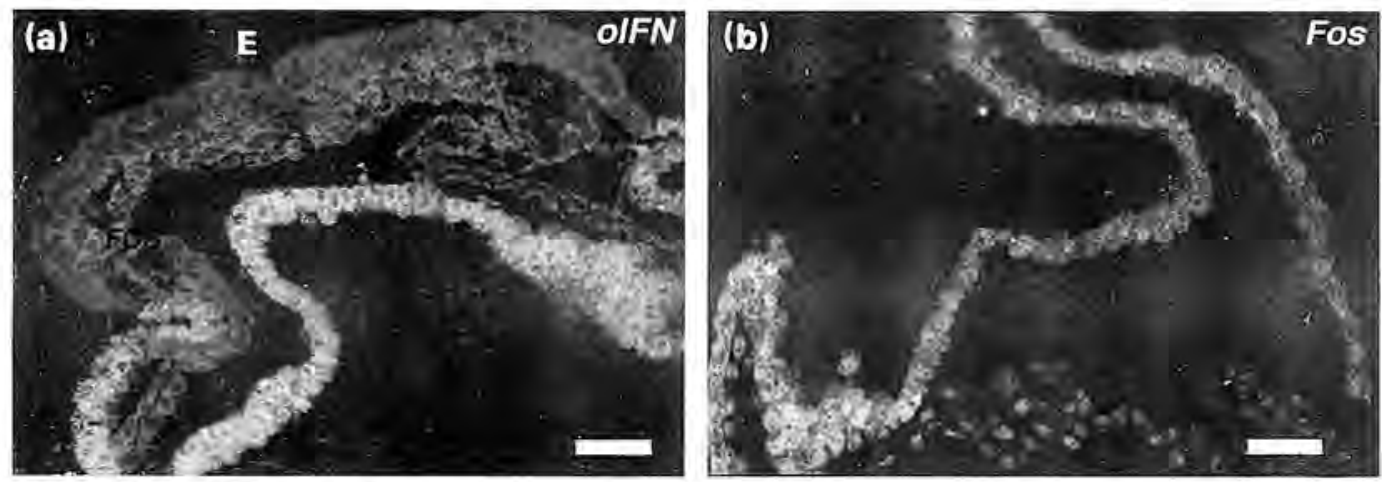

Fig. 2. Cellular localization by immunofluorescence of (a) ovine interferon $\tau$ (oIFN- $\tau$ ) and (b) c-Fos protein (Fos) in ovine conceptuses at day 14 . Scale bars represent $50 \mu \mathrm{m}$. E: embryo.

demonstrated in this study and the authors concluded that the protein could be synthesized by non-uterine tissues and transported to the endometrium where it accumulates and is released to the conceptus.

The second function of the trophoblast is the production of factors involved in the process of maternal recognition of pregnancy. The pioneer experiments of Rowson and Moor (1967) established that ovine conceptus proteins could extend the interoestrous interval when infused into the uterine lumen. Many studies have now led to the characterization of the antiluteolytic factors (also named ovine, caprine and bovine trophoblast protein-1: oTP, CTP, bTP, respectively) as interferons $\omega$ which are now classified as interferon $\tau$ (IFN- $\tau$ ) (review by Roberts et al, 1992). As shown by in situ hybridization (Farin et al, 1989, 1990) and immunocytochemistry (Wooding et al, 1991; Morgan et al., 1993), IFN- $\tau$ is produced specifically by the mononucleate cells of the extra-embryonic trophoblast (Fig. 2a). The expression of IFN- $\tau$ rises from the elongation stage, culminates when the conceptus has reached its maximal size and drops rapidly after implantation (Hansen et al, 1988; Charlier et al., 1989; Stewart et al., 1989). The control of IFN- $\tau$ expression is still under investigation. The initiation or induction of expression seems to be a preprogrammed event in the embryonic genome, since in vitro fertilized and cultured bovine embryos produce detectable amounts of IFN- $\tau$ at the blastocyst stage (Hernandez-Ledezma et al, 1992). However, maintenance of a high secretion rate is probably under exocrine control. Uterine growth factors such as insulin-like growth factor I (IGF-I) and IGF-II (Ko et al., 1991) and granulocyte-macrophage colony-stimulating factor (GM-CSF) (Imakawa et al., 1993) stimulate oTP expression and synthesis by cultured ovine conceptuses. Moreover, in co-cultures with uterine epithelial cells, oTP synthesis by isolated trophoblast cells is increased and maintained for 6-8 days after seeding by comparison with the rate of secretion by cells cultured alone (Reinaud et al., 1992). Whether these stimulatory factors are specific for IFN- $\tau$ expression or reflect an overall trophic effect on conceptus development remains to be determined. During the extensive growth of the conceptus the proto-oncogene c-fos is expressed by ovine (Fig. 2b) (Xavier et al., 1991) and caprine (F. Xavier and M. Guillomot, unpublished) trophoblast. Since this proto-oncogene is known to be involved in various processes of cell proliferation or differentiation, it is possible that it could control the growth and function of the trophoblast. One oTP gene presents an AP-1-like sequence (Nephew et al., 1993) which is known to be a binding domain for c-fos and jun proteins in the regulation of gene expression (Ransone and Verma, 1990). Thus, proto-oncogenes might be components of the regulatory complex that controls IFN- $\tau$ expression.

The arrest of the elongation process and the immobilization of the conceptus in the uterine lumen signal the end of the pre-attachment period. In sheep, punctate areas of contact of the trophoblast and the uterine epithelium are observed by day 14 (Guillomot et al., 1981). However, this type of attachment is still very loose and is easily disrupted during uterine flushing or tissue processing for histology. 


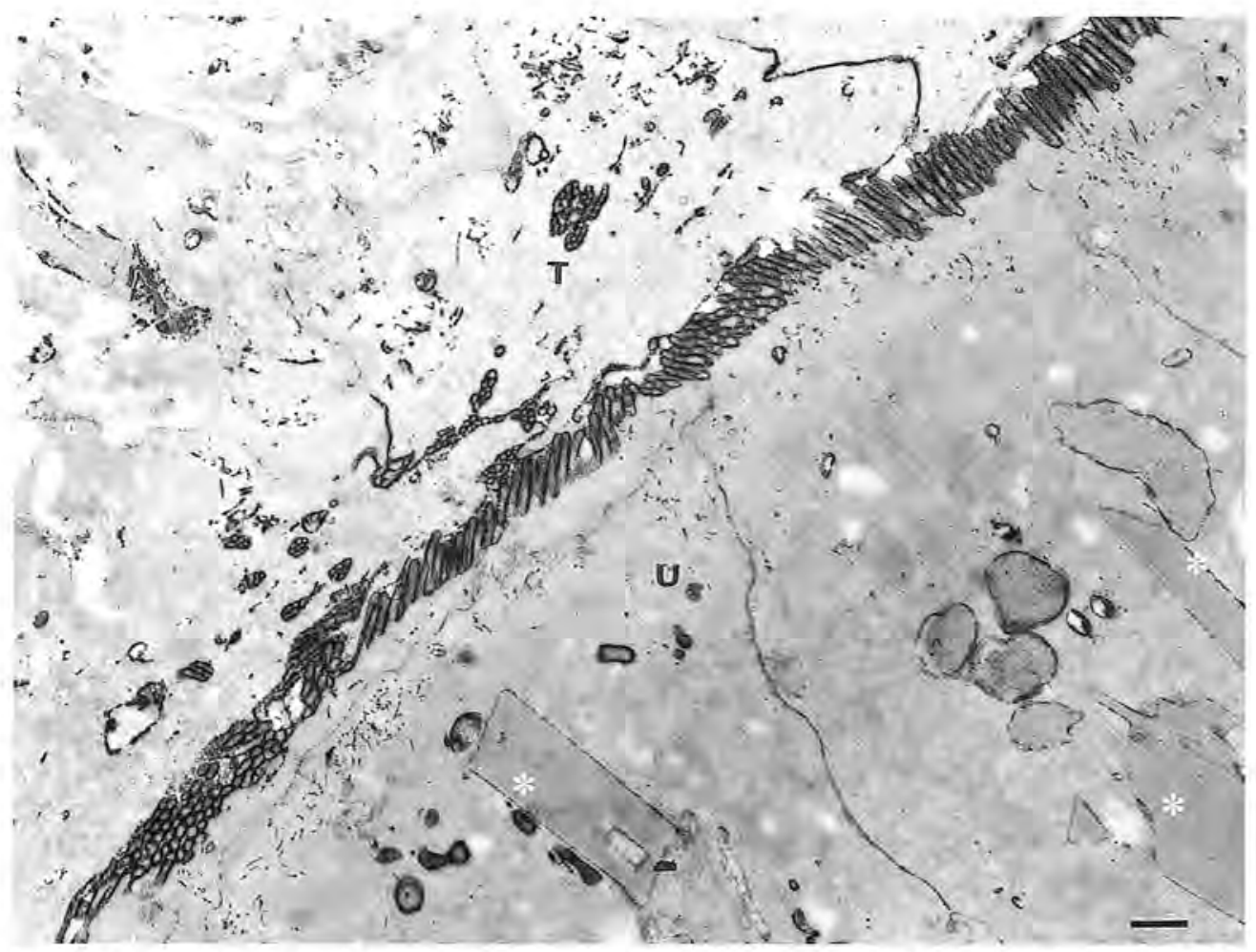

Fig. 3. Apposition area in sheep (day 17). The smooth apical membrane of the trophoblastic cells (T) is apposed on the tip of the microvilli of the uterine epithelial cells (U). Both cell membranes are stained by phosphotungstic acid. Note the presence of crystalline inclusions (asterisks) in the uterine cytoplasm. Scale bar represents $1 \mu \mathrm{m}$.

\section{Apposition Stage}

The conceptus can be flushed from the uterine horn without damaging the trophoblast as late as day 14, 17 and 18 in sheep, goats and cows, respectively. Thereafter, areas of cell contact between the trophoblast and the uterine epithelium are firm enough to be preserved during histological preparation. As shown by electron microscopy, the cell contacts are ensured by a close apposition of the trophoblastic cell membrane on the tips of the microvilli of the uterine cells (Fig. 3) by day 15 in sheep (Guillomot et al., 1981), by day 18 in goats (King, 1993) and by day 19-20 in cows (Leiser, 1975; Wathes and Wooding, 1980).

Apposition starts in the embryonic zone and spreads towards the ends of the conceptus. In sheep, early signs indicating that apposition is imminent are modifications of the endometrial tissue by day 15 . Increases of the vascular permeability and stromal oedema have been reported (Boshier, 1970). The luminal surface of the uterine caruncles becomes wrinkled and concave at the centre (Fig. 4a). After flushing the uterine lumen to collect embryos, remnants of trophoblast can be found trapped in the deep caruncular depressions (Fig. 4b). This transformation of the caruncular structure is a prelude to the cup-like aspect of the ovine placentomes. This remodelling of the endometrium may be under the control of matrix metalloproteinases which are expressed by the stromal fibroblasts in the ovine uterus (Salamonsen et al., 1993).

Concomitant with early attachment is evidence of embryonic differentiation. At this stage enclosure of the embryo within the chorionic vesicle begins through folding of the trophoblast that surrounds it (Fig. 5a, b). This process will give rise to the amniotic cavity (Ramsey, 1982). The primitive streak is formed; somites are apparent; and in the more advanced embryo the neural tube has been enclosed in 

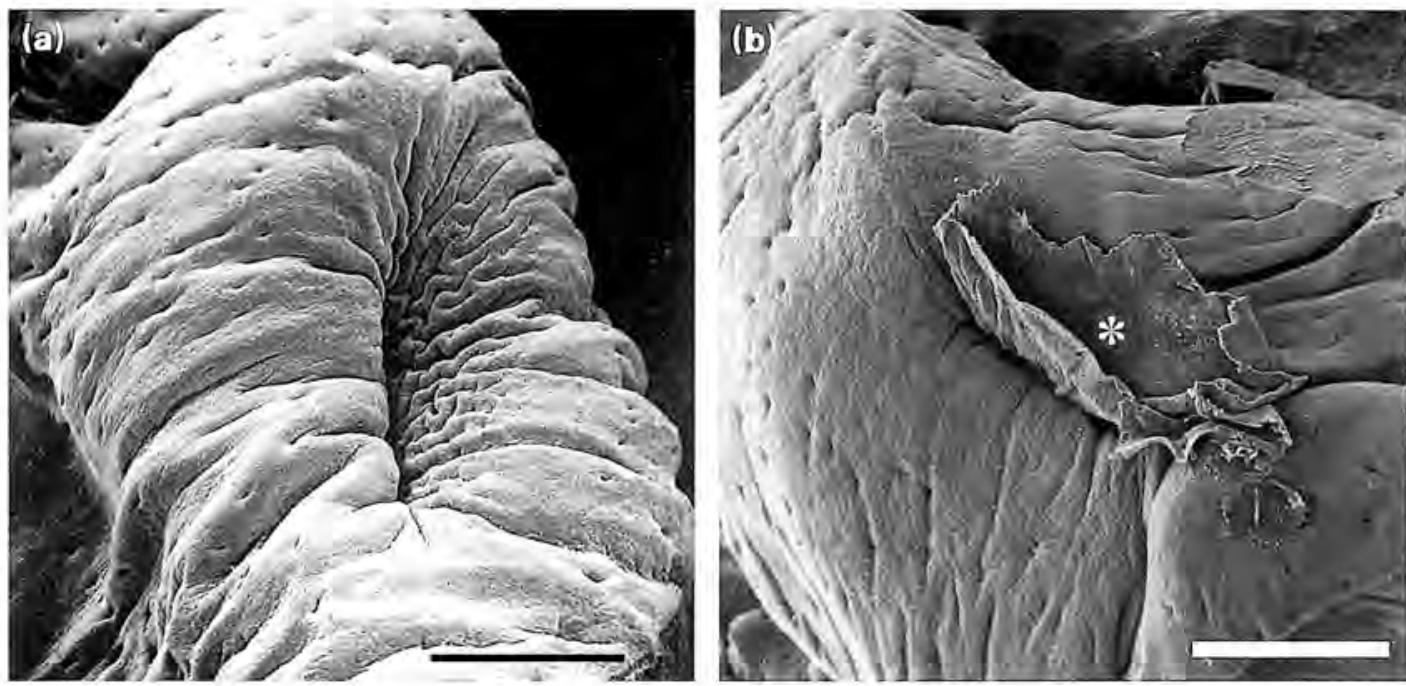

Fig. 4. Scanning electron micrograph of ovine day-15 caruncles which present a deep central depression and a wrinkled luminal surface (a) and remnant of trophoblast (asterisk) engulfed in the caruncular depression (b). Scale bars represent $50 \mu \mathrm{m}$.

the region of the hind gut. The trophoblast surface shows ridges (Fig. 5c) that correspond to the imprint left by the undulated surface of the caruncle. On the trophoblast apposed to the intercaruncular endometrium, small villi or papillae develop (Fig. $5 \mathrm{~d}$ ) and project into the openings of the uterine glands (Guillomot et al., 1981; Guillomot and Guay, 1982; Wooding et al., 1982). These processes facilitate the immobilization and subsequent apposition between the trophoblast and the uterine epithelium. Moreover, the villi may constitute a privileged route for the absorption of glandular secretions. This glandular-trophoblast interaction is transient, for it is not observed later in pregnancy and is replaced by para-placental formations named areolae (Wimsatt, 1950). Early in the attachment process, the trophoblastic cells undergo profound structural and functional modifications. The cells lose their rounded appearance to become flat and spindle-shaped and the apical microvilli are reduced in length and density on the cell surface (Guillomot et al., 1981; Guillomot and Guay, 1982). These structural changes are initially localized in the trophoblast surrounding the embryo (Fig. $5 \mathrm{e}$ ), whereas in the distal part of the conceptus the cells retain pre-attachment characteristics (Fig. 5f). These observations suggest a major reorganization of cell polarity, which seems to be a prerequisite to implantation (Denker, 1993). During this period of pregnancy the genetic programme of the trophoblastic cells is also remarkably altered. Expression of IFN- $\tau$ stops abruptly after implantation. In sheep, the arrest of oTP expression is well correlated with the initiation of attachment since the protein is undetectable in the implanting trophoblast close to the embryonic area (Fig. 6a) while it is still present in the trophoblastic cells in the more distal parts of the conceptus (Fig. 6b) (Guillomot et al., 1990). It is noteworthy that the c-fos proto-oncogene is also downregulated at implantation and this extinction follows the same cellular distribution as that of oTP (Fig 6c, d) (Xavier et al., 1991). These observations suggest strongly that there is an interrelationship in the regulation of the two genes or that both are controlled by the same, as yet unknown, factor(s).

\section{Adhesion Stage}

Shortly after attachment has occurred, the adhesion between the trophoblast and the uterine epithelium is reinforced by penetration of uterine microvilli within folds of the plasma membrane of the trophoblastic cells. Thereafter, interlocking of microvilli is established and this will maintain a close adhesion between the two tissues throughout pregnancy. Establishment and maintenance of cell contact 

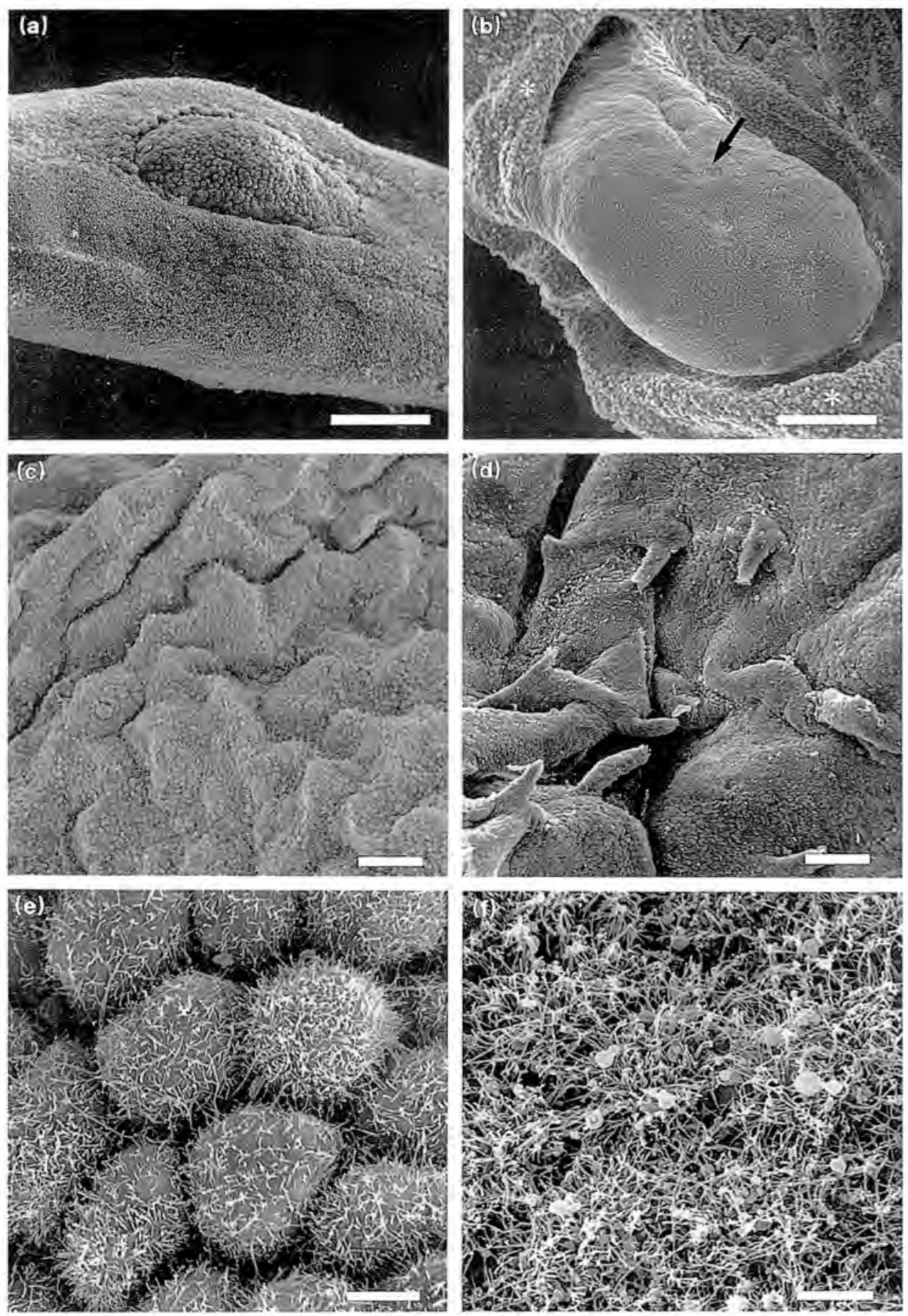

Fig. 5. Ovine conceptuses at day $14(\mathrm{a}, \mathrm{b})$ and at day $15(\mathrm{c}-\mathrm{f})$. Characteristic aspect of the embryonic disc during the pre-attachment period (a) and at the beginning of apposition (b) with amniotic folds (asterisk) surrounding the embryo on which the primitive streak (arrow) is differentiated. Scale bars represent $100 \mu \mathrm{m}$. (c) Folded surface of the trophoblast which was apposed on a uterine caruncle and (d) villous trophoblast collected on the intercaruncular glandular endometrium. Scale bars represent $100 \mu \mathrm{m}$. Structure of the apical surface of trophoblastic cells in the vicinity of the embryo (e) and in the non-implanted distal trophoblast (f). Scale bars represent $10 \mu \mathrm{m}$. 

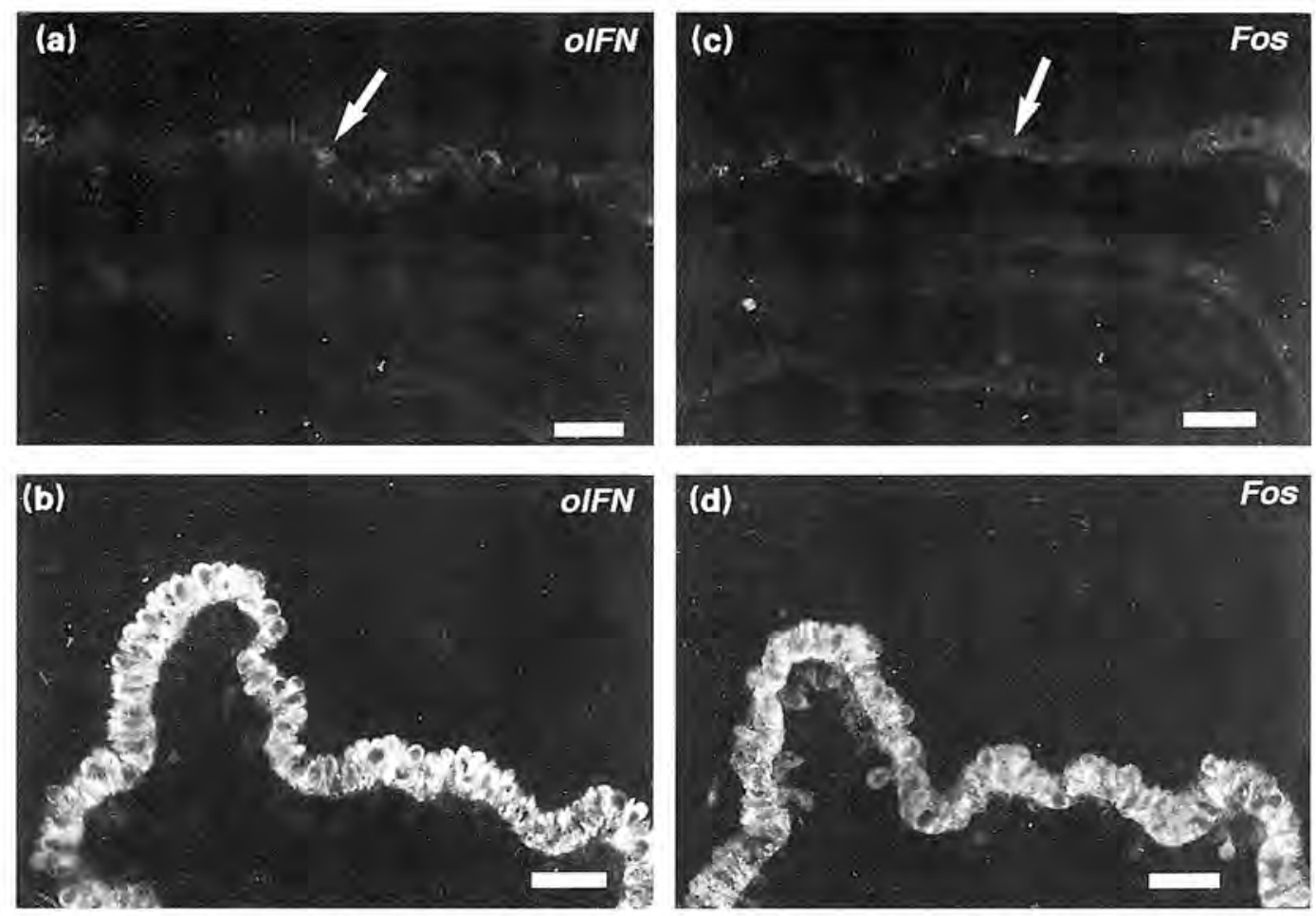

Fig. 6. Immunofluorescence localization of ovine interferon $\tau$ (oIFN- $\tau$ ) (a, b) and c-Fos protein (Fos) (c, d) in day 15 ovine conceptus. oIFN- $\tau$ and c-Fos proteins are not detected in the trophoblast (arrows) surrounding the embryo $(a, c)$, while a positive reaction is still obtained in the distal trophoblast $(b, d)$. Figures are from serial sections from the same conceptus. Scale bars represent $50 \mu \mathrm{m}$.

is likely to involve glycosylated membrane proteins. In sheep, the thickness of the glycocalyx increases on the outer membrane of the trophoblastic cells during the apposition process (Guillomot et al., 1982) and as shown by phosphotungstic acid (PTA) staining a glycoprotein coat is always present at the utero-trophoblast interface (Figs 7 and 8 a). As adhesion proceeds, the cuboidal uterine epithelium becomes very flat and is reduced to a narrow layer (Fig. 7), partly syncytial and areas of degeneration have been observed (King et al., 1982). Syncytial transformation of the uterine epithelium is a consistent feature in the process of implantation in ruminants (Wooding, 1992; King, 1993). It is now well established that the uterine syncytium is formed after the migration and fusion of the trophoblastic binucleate cells with uterine cells (Wooding, 1982). During the process, glycoprotein granules, which are characteristic features of the binucleate cells (Fig. 8a), are transported to the basal pole of the uterine syncytium (Fig. 8b) (Wooding, 1980). In goats and sheep, a partial stromal invasion occurs with projection of cytoplasmic processes through the basal lamina (Fig. 8b) (Lawn et al., 1969; Guillomot et al., 1981). The formation of the syncytium represents the most invasive phase of implantation in ruminants. In sheep and goats, the syncytium is persistent and grows by migration of the binucleate cells throughout pregnancy. In cows the syncytial masses are replaced by epithelial cells once the binucleate cells have discharged their granular content to the uterine stroma (Wooding, 1982).

It is likely that the binucleate cells play a major role in placental function. The binucleate cells differentiate from mononucleate trophoblastic cells at the beginning of implantation and throughout pregnancy and they represent about $20 \%$ of the trophoblastic cells (Wooding, 1982). These specific cells of the ruminant trophoblast produce steroid hormones and various proteins some of which have been identified (Wooding, 1992). Ovine (Martal et al., 1977; Watkins and Reddy, 1980; Wooding, 1981) and bovine (Wooding and Beckers, 1987) placental lactogen hormones (oPL and bPL, respectively) have been localized both in the binucleate cells and in the uterine syncytium. Later in pregnancy oPL and bPL 


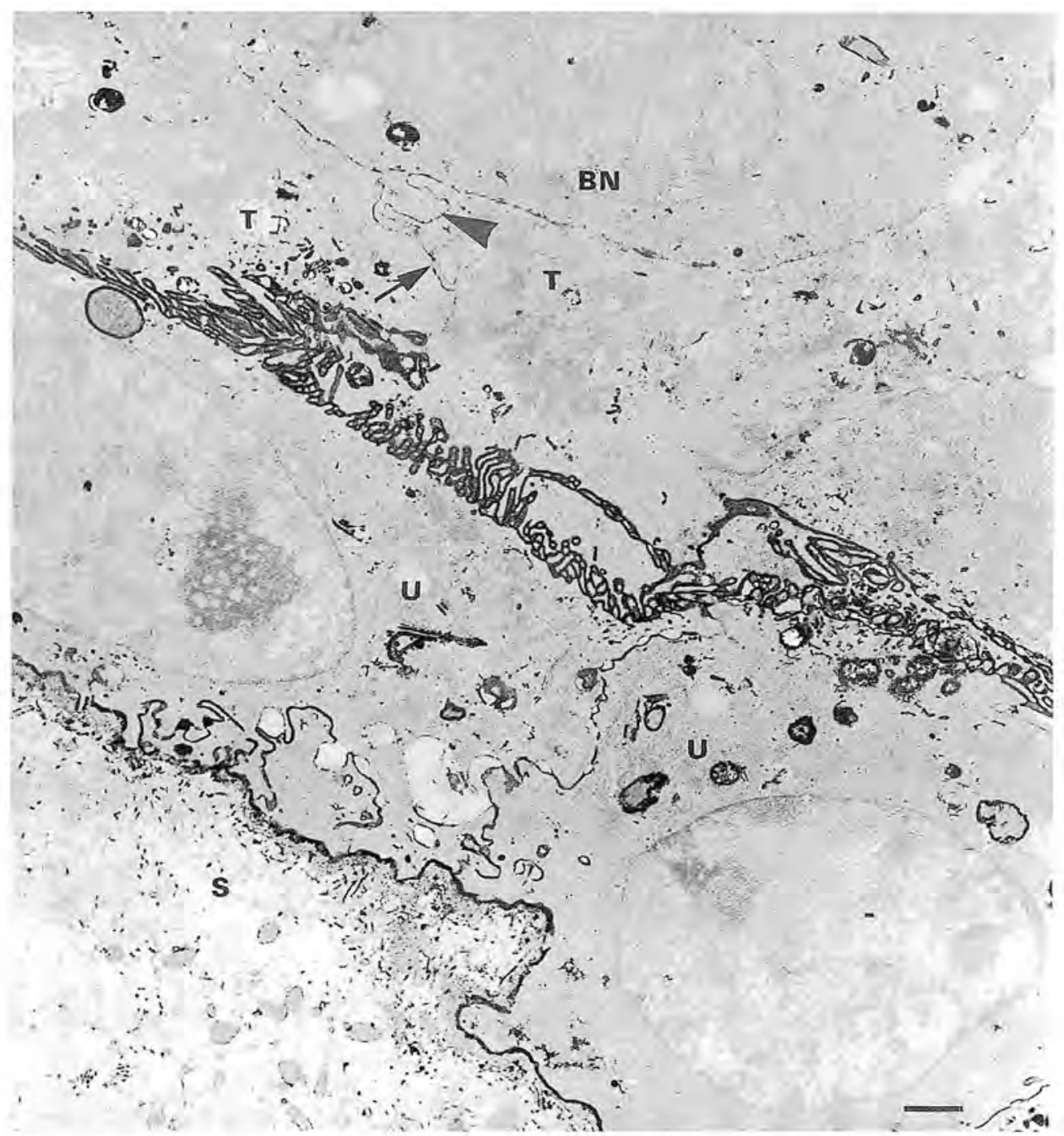

Fig. 7. Adhesion area in sheep (day 18). A microvillar junction links the flattened uterine epithelial cells. (U) and the trophoblastic cells (T). A migrating binucleate cell (BN) intrudes (arrowhead) in the tight junction (arrow) of the mononucleate trophoblastic cells. (S): uterine stroma. Phosphotungstic acid staining. Scale bar represents $1 \mu \mathrm{m}$.

are co-localized with an unidentified glycoprotein named SBU-3 antigen (Lee et al,, 1986; Morgan $e t$ al., 1989). These observations indicate that synthesis of proteins in the binucleate cells is continuously modulated or that different populations of binucleate cells differentiate during pregnancy. Wooding et al. (1994) reported that the SBU-3 antigen is present within vesicles concentrated in the cytoplasm of the migrating front of the binucleate cells. However, it is unlikely that this protein is involved in migration of binucleate cells, as the process is observed well before SBU-3 is present in the cells (Lee et al., 1986; Morgan et al., 1989). Characterization of the SBU-3 antigen would greatly help in understanding its role in cell migration during placentation in ruminants. Another group of placental glycoproteins with molecular masses ranging from 78 to $60 \mathrm{kDa}$ have been detected in binucleate cells. Because of their presence in the maternal serum during pregnancy they are referred to as pregnancy specific proteins (PSP) with different terminologies according to various authors (PSPB: Butler et al., 1982; PAG: Zoli 


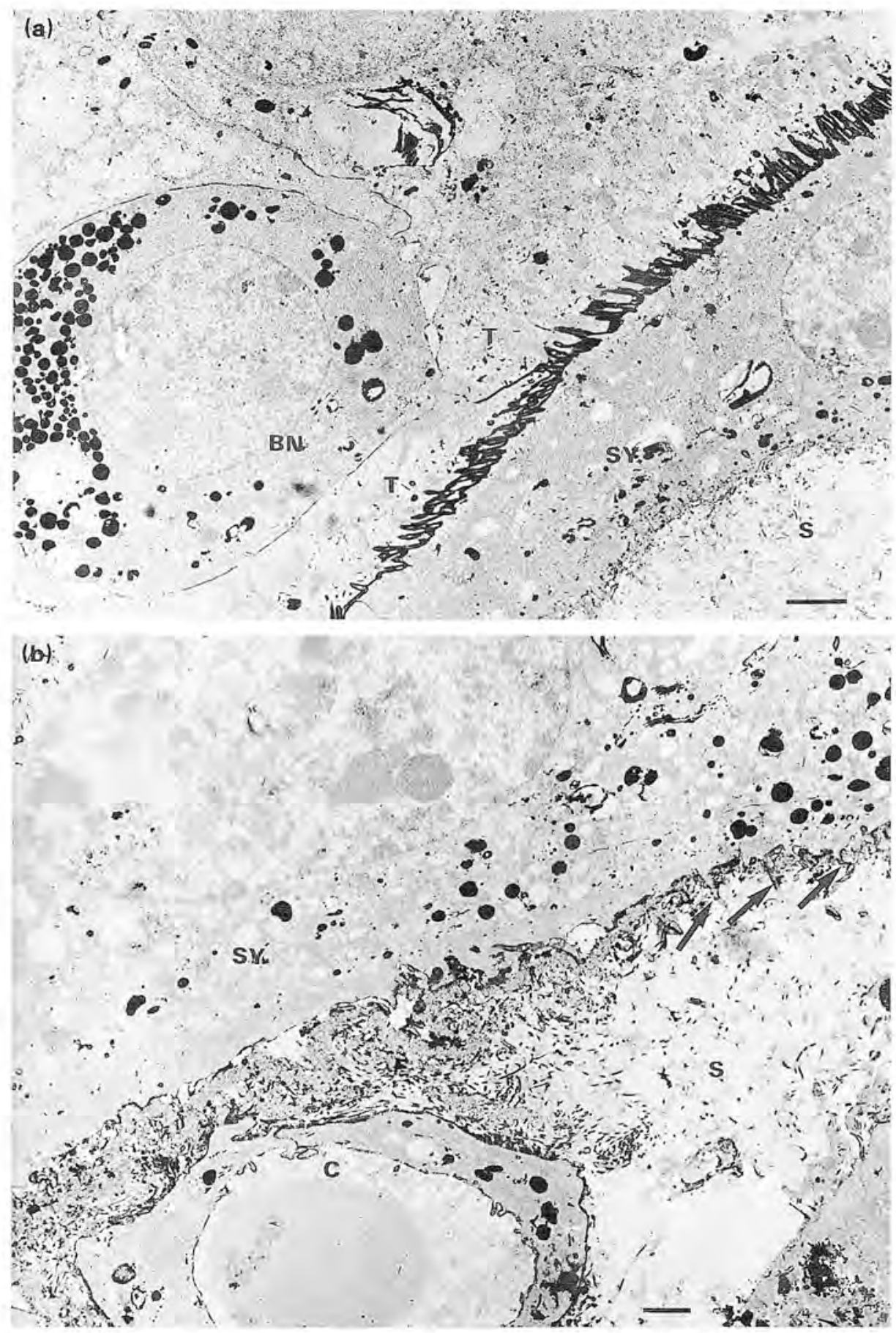

Fig. 8. Adhesion area in sheep (day 18). (a) A binucleate cell (BN) with characteristic phosphotungstic acid-stained granules is still away from the uterine syncytium (SY) adherent to mononucleate trophoblastic cells (T); uterine stroma (S), Scale bar represents $2 \mu \mathrm{m}$. (b) Cytoplasm of the basal pole of a uterine syncytium (SY) which shows phosphotungstic acid-stained granules and cytoplasmic processes (arrows) that project into the uterine stroma (S) through the basal lamina; C: uterine capillary. Scale bar represents $1 \mu \mathrm{m}$. 

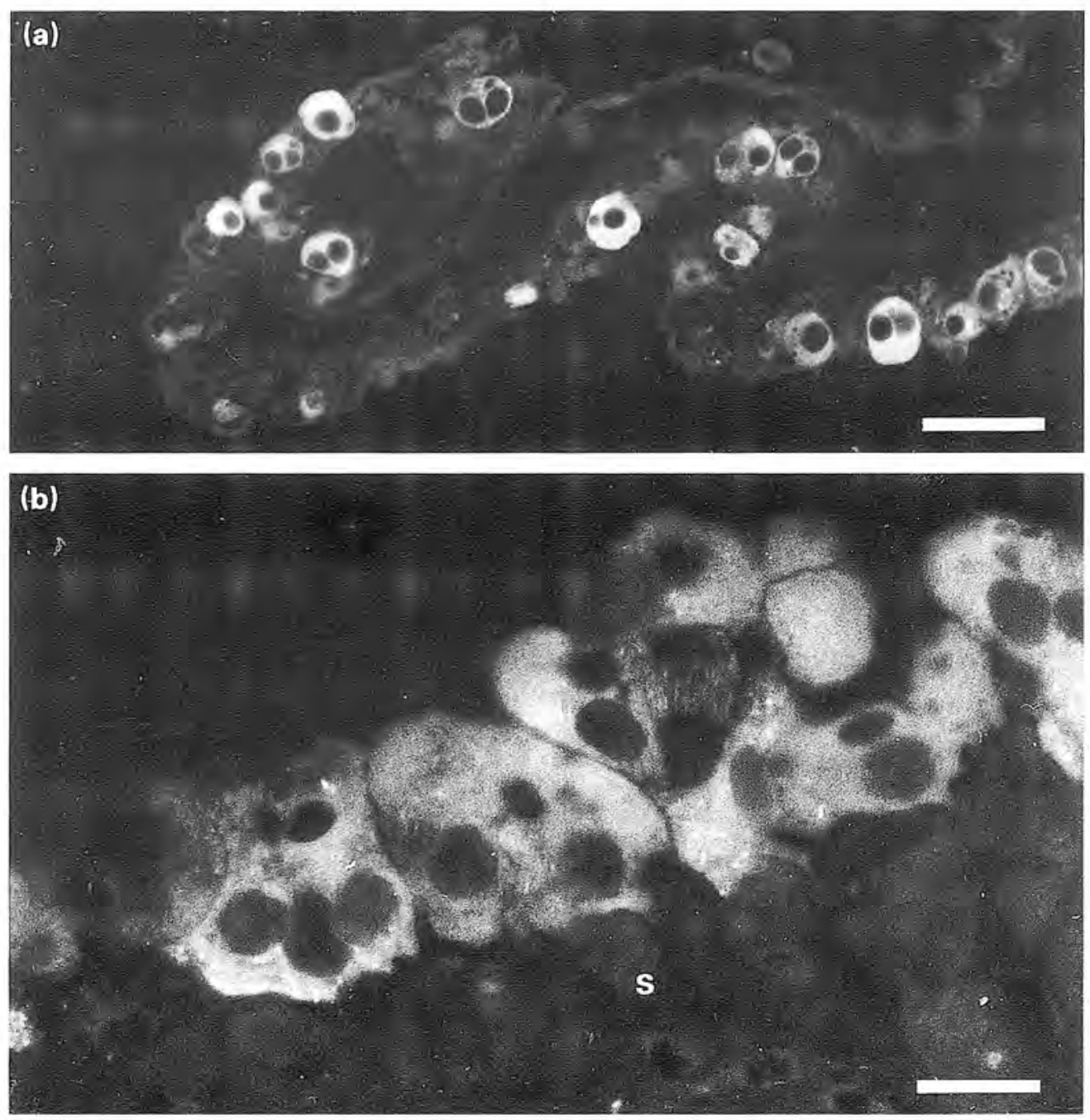

Fig. 9. Cellular localization by immunofluorescence of pregnancy specific protein (Psp60) in sheep (a) trophoblast binucleate cells, and (b) uterine syncytium at day 17; S: uterine stroma. Scale bars represent $15 \mu \mathrm{m}(\mathrm{a})$ and $50 \mu \mathrm{m}(\mathrm{b})$.

et al., 1992a; Psp60: Mialon et al., 1994). All these proteins are immunologically related and are used as markers in the diagnosis of pregnancy in cows (Sasser et al.., 1986; Humblot et al., 1988), sheep (Ruder et al., 1988) and goats (Humblot et al., 1990). It has been shown that bovine PSPB is a specific product of the binucleate cells (Reimers et al., 1985). Immunocytochemical studies showed that PSP were present within the cytoplasmic granules of the binucleate cells and of the uterine syncytium (Eckblad et al., 1985; Zoli et al., 1992b). Likewise, in all ruminants we have studied, Psp60 is specifically present in the binucleate cells (Fig. 9a) and in the cytoplasm of the uterine syncytial tissue (Fig. 9b). Molecular cloning of the cDNA encoding PAG has revealed that these proteins belong to the aspartic proteinase family but are enzymatically inactive (Xie et al., 1991). The fact that proteolytic proteins are produced by the most invasive trophoblastic cells suggests that the PSP are probably involved in the process of syncytium formation. The presence of conceptus-derived proteins (placental lactogens and PSP) in the uterine syncytium and in the maternal serum indicates that the migration of the binucleate cells and formation of the syncytium mediate the delivery of these products into the maternal circulation. 
Table 1. Chronology of the major events during peri-implantation in domestic ruminants

\begin{tabular}{|c|c|c|c|}
\hline Event & Sheep & Goats & Cows \\
\hline Entry into the uterus & Day 4 & Day 4 & Day 4 \\
\hline Blastocyst stage & Day 6 & Day 6 & Day 6-7 \\
\hline Hatching from the $\mathrm{ZP}$ & Day 8 & Day 8-9 & Day $9-10$ \\
\hline Elongation & Day 11 & Day 13 & Day 13 \\
\hline Apposition ${ }^{3}$ & Day 15 & Day $18^{b}$ & Day $19^{b}-20$ \\
\hline Adhesion & Day $16^{6}$ & Day $19-20$ & Day $21-22$ \\
\hline
\end{tabular}

Day: days after insemination (day 0 ).

ZP: zona pellucida.

"In the embryonic area; 'differentiation of the binucleate cells.

\section{Conclusions}

The main steps of the peri-implantation period are summarized in Table 1 . The development of a close adhesion between the trophoblast and the uterine epithelium in ruminants induces profound changes in cell function and structure in both tissues. Implantation begins by apposition which is initiated around the embryonic area and spreads progressively to the ends of the conceptus. The process involves both the intercaruncular and the caruncular endometrium. However, the fetal cotyledons will develop only on the uterine caruncles giving rise to two distinct placental structures with different functions. The intercotyledonary placenta is involved in reabsorption of macromolecular content of the uterine glands whereas the cotyledonary placentomes are involved in transfer of gas and diffusible molecules (Davies and Wimsatt, 1966). As suggested by the progressive arrest of expression of oTP and proto-oncogene c-fos during the early stages of attachment, the genomic programme of the trophoblastic cells is probably under a local and subtle regulation which remains to be characterized. With the arrest of the major signalling factor, i.e. IFN- $\tau$, new molecules need to be transmitted to the mother to ensure maintenance of pregnancy. It is likely that migration of the binucleate cells and the subsequent transfer of molecules (placental lactogens, pregnancy specific proteins) to the maternal tissues and serum represent the setting up of this relay.

\section{References}

Bazer FW, Roberts RM, Sharp III DC and Thatcher WC (1981) Uterine proteins synthesized during the progestative period and pregnancy. In Llterus et Fécondité pp 17-32 Eds C Boury-Heller, P Mauleon and $Y$ Rochet. Masson, Paris

Boshier DP (1970) The pontamine blue reaction in pregnant sheep uteri Joumal of Reproduction and Ferility 22 595-596

Butler IE, Hamilton WC, Sasser RG, Ruder CA. Hass GM and Williams RJ (1982) Detection and partial characterization of two bovine pregnancy-specific proteins Biology of Reproducfion 26 925-933

Carnegie JA, McCully ME and Robertson HA (1985) The early development of the sheep trophoblast and the involvement of cell death American Joumal of Anatomy 174 471-488

Charlier M, Hue D, Martal J and Gaye P (1989) Cloning and expression of CDNA encoding ovine trophoblastin: its identity with a class Il alpha interferon Gene 77 341-34s

Davies J and Wimsatt WA (1966) Observations on the fine structure of the sheep placenta Acta Anatomica 65 I82-22.3
Denker HW (1993) Implantation: a cell biological paradox Journal of Experimental Zoology 266 541-558

Dore JJE, Liu KH and Roberts RM (1992) Endometrial and embryonic expression of ovine retinol-binding protein Biology of Reproduction 46 (Supplement 1) 142

Eckblad WP, Sasser RG, Ruder CA, Panlasigui $P$ and Kucznski T (1985) Localization of pregnancy-specific protein B (PSPB) in bovine placental cells using a glucose oxidaseanti-glucose oxidase immunohistochemical stain Joumal of Animal Science 61 (Supplement 1) Abstract 55

Farin CE. Imakawa K and Roberts RM (1989) in sifu localization of mRNA for the interferons, ovine trophoblast protein-1. during early embryonic development of the sheep Molecular Endocrinology 3 1099-1107

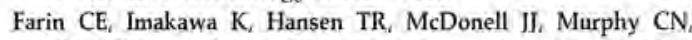
Farin PW and Roberts RM (1990) Expression of trophoblasi interferon genes in sheep and cattle Biology of Reproduction $43210-218$ 
Guillomot M and Fléchon JE (1990) Place de la microscopie dans I'étude des conditions de l'implantation chez les ruminants Contraception Ferilité Sexualilé 18 875-885

Guillomot M and Guay P (1982) Ultrastructural features of the cell surfaces of the uterine and trophoblastic epithelia during embryo attachment in the cow Anatomical Record $204 \quad 315-322$

Guillomot M, Flèchon IE and Wintenberger-Torrès S (1981) Conceptus attachment in the ewe: an ultrastructural study Placenta 2 169-182

Guillomot M, Fléchon JE and Wintenberger-Torres S (1982) Cytochemical studies of uterine and trophoblastic surface coats during blastocyst attachment in the ewe Journal of Reproduction and Fertility 65 I-8

Guillomot M, Reinaud P. Charpigny G and Martal J (1988) Embryo-uterine interactions during early stages of pregnancy in domestic mammals Reproduction Nutrilion Development 28 1629-1048

Guillomot M, Michel C, Gaye P, Charlier M, Trojan J and Martal I (1990) Cellular localization of an embryonic interferon, ovine trophoblastin and its mRNA in sheep embryos during early pregnancy Biology of the Cell 68 205-211

Hansen TR, Imakawa K, Polites HG, Marotti KR, Anthony RV and Roberts RM (1988) Interferon RNA of embryonic origin is expressed transiently during early pregnancy in the ewe Journal of Biological Chemistry 263 12801-12804

Harney JP, Ott TL, Geisert RD and Bazer RW (1993) Retinolbinding protein gene expression in cyclic and pregnant endometrium of pigs, sheep and cattle Biology of Reproducfion 49 1066-1073

Hernandez-Ledezma JJ, Sikes JD, Murphy CN, Watson AJ, Schultz GA and Roberts RM (1992) Expression of bovine trophoblast interferon in conceptuses derived by in vitro techniques Biology of Reproduction 47 374-380

Humblot P, Camous S, Martal J, Charlery J, Jeanguyot N, Thibier M and Sasser RG (1988) Diagnosis of pregnancy by radioimmunoassay of a pregnancy-specific protein in the plasma of dairy cows Theriogenology 30 257-208

Humblot P, De Montigny G, Jeanguyot N, Tetedole F, Payen B, Thibier M and Sasser RG (1990) Pregnancy-specific protein $B$ and progesterone concentrations in French Alpine goats throughout gestation Joumal of Reproduction and Fertility 89 205-212

Imakawa K, Helmer SD, Nephew KP, Meka CSR and Christenson RK (1993) A novel role of Gm-CSF; enhancement of specific interferon production, ovine trophoblast protein-1 Endocrinology 132 1869-1871

Kazemi M, Amann JF, Keisler DH, Ing NH, Roberts RM, Morgan G and Wooding FBP (1990) A progesteronemodulated. low-molecular weight protein from the uterus of the sheep is associated with crystalline inclusion bodies in uterine epithelium and embryonic trophectoderm Biology of Reproduction 43 80-96

King GJ (1993) Comparative placentation in ungulates Journal of Experimental Zoology 266 588-602

King GJ, Atkinson BA and Robertson HA (1982) Implantation and early placentation in domestic ungulates Journal of Reproduction and Fertility Supplement 31 17-30

Ko Y, Lee CY, Ott TL, Davis MA, Simmen RCM, Bazer FW and Simmen FA (1991) Insulin-like growth factors in sheep uterine fluids concentrations and relationship to ovine trophoblast protein-1 production during early pregnancy Biology of Reproduction 45 135-142
Lawn AM, Chiquoine AD and Amoroso EC (1969) The development of the placenta in the sheep and goat: an electron microscope study Joumal of Anatomy 105 $557-578$

Lee CS, Wooding FBP and Brandon MR (1986) Ultrastructural immunogold investigation of the function and diversity of binucleate cells in the ovine placenta using a monodonal antibody Placenta 7 495-504

Leiser R (1975) Kontaktaufnahme zwischen Trophoblast und Uterusepithel wärhend der frühen Implantation beim Rind Anatomia Histologia Embryologia 4 63-86

Liu KH and Godkin JD (1992) Characterization and immunolocalization of bovine uterine retinol-binding protein Biology of Reproduction 47 1099-1104

Martal J, Djiane J and Dubois MP (1977) Immunofluorescent localization of ovine placental lactogen Cell and Tissue Research 184 427-4.33

Mialon MM, Renand G, Camous S, Martal J and Menissier F (1994) Detection of pregnancy by radioimmunoassay of a pregnancy serum protein (Psp60) in cattle Reproduction Nutrition Development 34 65-72

Morgan G, Wooding FBP, Beckers JF and Friesen HG (1989) An immunological cryo-ultrastructural study of a sequential appearance of proteins in placental binudeate cells in early pregnancy in the cow Joumal of Reproduction and Ferility $\mathbf{8 6}$ $745-752$

Morgan G, Wooding FBP and Godkin JD (1993) Localization of bovine trophoblast protein-1 in the cow blastocyst during implantation: an immunological cryoultrastructural study Placenta $1464 \mathrm{I}-649$

Nephew KP, Whaley AE, Christenson RK and Imakawa K (1993) Differential expression of distinct mRNAs for ovine trophoblast protein-1 and related sheep type I interferons Biology of Reproduction 48 768-778

Ramsey EM (1982) Placentation in general. In The Placentr Human and Animal. pp 3-56. Praeger. New York

Ransone LJ and Verma IM (1990) Nuclear proto-oncogenes Fos and Ism Annual Revieto of Cell Biology 6 539-557

Reimers TJ. Sasser RG and Ruder CA (1985) Production of pregnancy-specific protein by bovine binucleate trophoblastic cells Biology of Reproduction 32 (Supplement 1) Abstract 55

Reinaud P, Charpentier N, Bertin J and Guillomot M (1992) Secretion of ovine trophoblastic interferon is stimulated by uterine epithelial cells in vitro Satellite Sympositum on Endocrinology of Embryo-Endomelrial Interacions (Bordeaux) Abstract 55

Roberts RM, Cross IC and Leaman DW (1992) Interferons as hormones of pregnancy Endocrine Review 13 432-452

Rowson LEA and Moor RM (1967) The influence of embryonic tissue homogenate infused into the uterus, on the life-span of the corpus luteum in the sheep Journal of Reproduction and Fertility $13511-516$

Ruder CA, Sasser RG, Dahmen J] and Stellflug IN (1988) Detection of pregnancy in sheep by radioimmunoassay of sera for pregnancy-specific protein B Theriogenology 29 905-912

Salamonsen LA, Nagase H, Suzuki R and Wooley DE (1993) Production of matrix metalloproteinase- 1 (interstitial collagenase) and matrix metalloproteinase-2 (gelatinase- $A$ : $72 \cdot \mathrm{kDa}$ gelatinase) by ovine endometrial cells in vitro. Different regulation and preferential expression by stromal fibroblasts Journal of Reproduction and Fertility 98 $583-589$ 
Sasser RG, Ruder CA, Ivani KA Butler JE and Hamilton WC (1986) Detection of pregnancy by radioimmunoassay of a novel pregnancy-specific protein in senum of cows and a profile of serum concentration during gestation Biology of Reproduction $35936-942$

Stewart HJ, McCann SHE, Northrop AJ, Lamming GE and Flint APF (1989) Sheep antiluteolytic interferon: CDNA sequence and analysis of mRNA levels Joumal of Molecular Endocrinology 2 ó $5-70$

Thomas PGA, Leslie MV and Hansen PJ (1992) Retinol-binding protein is produced by the bovine endometrium and accumulates in uterine secretions in a progesteronedependent manner Animal Reproduction Science 27 55-60

Wathes DC and Wooding FBP (1980) An electron microscopic study of implantation in the cow American Journal of Anatomy 159 285-306

Watkins WB and Reddy S (1980) Ovine placental lactogen in the cotyledonary and intercotyledonary placenta of the ewe Jotamal of Reproduction and Ferfility 58 411-474

Wimsatt WA (1950) New histological observations on the placenta of the sheep American Journal of Anatomy $\mathbf{8 7}$ $391-458$

Wintenberger-Torrès S and Fléchon JE (1974) Ultrastructural evolution of the trophoblast cells of the preimplantation sheep blastocyst from day 8 to 18 Journal of Anatomy 118 143-153

Wooding FBP (1980) Electron microscopic localization of binucleate cells in the sheep placenta using phosphotungstic acid Biology of Reproduction 22 357-365

Wooding FBP (1981) Localization of ovine placental lactogen in sheep placentomes by electron microscope immunocytochemistry Journal of Reproduction and Fertility 62 15-19

Wooding FBP (1982) The role of the binucleate cell in ruminant placental structure Jotimal of Reproduction and Fertility Supplement 31 31-39
Wooding FBP (1992) Current topic: the synepitheliochorial placenta of ruminants: binucleate cell fusions and hormone production Placenta 13 101-113

Wooding FBP and Beckers JF (1987) Trinucleate cells and ultrastructural localization of bovine placental lactogen Cell and Tissue Research 247 667-673

Wooding FBP, Staples LD and Peacock MA (1982) Structure of trophoblast papillae on the sheep conceptus at implantation Journal of Anatomy 134 507-512

Wooding FBP, Morgan G and Roberts RM (1991) Quantitative immunogold ultracryomicrotome studies of the distribution of perimplantation proteins in the sheep Cell and Tissue Research $26583-93$

Wooding FBP, Morgan G, Brandon MR and Camous S (1994) Membrane dynamics during placental cell migration through tight junctions. Cell and Tissue Research 276 387-397

Xavier F, Guillomot M, Charlier M, Martal J and Gaye P (1991) Co-expression of the proto-oncogene FOS $(c-f o s)$ and an embryonic interferon (ovine trophoblastin) by sheep conceptus during implantation Biology of the Cell 73 27-33

Xie S, Low BG, Nagel RJ, Kramer KK, Anthony RV, Zoli AP, Beckers JF and Roberts RM (1991) Identification of the major pregnancy-specific antigens of cattle and sheep as inactive members of the aspartic protemase family Proceedings of the National Academy of Sciences USA 88 10247-10251

Zoli AP, Guilbaut LA, Delahaut P, Ortiz WB and Beckers JF (1992a) Radioimmunoassay of a bovine pregnancyassociated glycoprotein in serum: its application for pregnancy diagnosis Biology of Reproduction 46 83-92

Zoli AP, Demez P, Beckers JF, Reznik M and Beckers A (1992b) Light and electron microscopic immunolocalization of bovine pregnancy-associated glycoprotein in the bovine placentome Biology of Reproduction 46 623-629 